\title{
Theoretical Validity of Problem Focused-Coping Skill Guideline to Develop Students' Critical Thinking Skills
}

\author{
(Validitas Teoritik Panduan Problem Focused-Coping Skills untuk Menumbuhkan Keterampilan \\ Berpikir Kritis Siswa)
}

\author{
Nur Hidayah $^{1 *}$, Anis Tri Yuliana ${ }^{2}$, Husni Hanafi ${ }^{1}$ \\ ${ }^{1}$ Department of Guidance and Counseling, Faculty of Education, Universitas Negeri Malang, \\ Semarang St. No. 5, Malang, East Java, 65145 Indonesia \\ ${ }^{2}$ Department of Guidance and Counseling, Sekolah Tinggi Keguruan dan Ilmu Pendidikan PGRI Sumenep, \\ Trunojoyo St., Gedungan, East Java, 69451 Indonesia \\ *corresponding author, e-mail: nur.hidayah.fip@um.ac.id
}

Article received: September $15^{\text {th }} 2020$; revised: October $19^{\text {th }} 2020$; accepted: November $25^{\text {th }} 2020$

\begin{abstract}
Critical thinking skills are central for students to become human resources with character. The process of developing thinking skills is currently done contextually within the implementation of learning materials, while critical thinking skills are also needed in everyday life situations. Developmental counselling services through the Problem Focused-Coping Skill (PFCS) strategy are an alternative to foster critical thinking skills through contextual situations in students' daily lives. Anchored by a research and development model through preliminary studies, product development, and expert validation, the present study unraveled the theoretical validity of PFCS strategy to enhance students' critical thinking skills. Participants involved were evaluators of product feasibility, namely counselling experts, learning media experts, and prospective users. Analysis of the assessment employed descriptive statistics and Aiken acceptance analysis. The results showed that: (1) there was a need for product development based on literature review and empirical data, (2) the PFCS strategy has been successfully developed in the form of format and content in the developmental service function to build high school students' critical thinking skills, (3) the assessment of the counselling experts, learning media experts, and users show the validity index in the appropriate and acceptable categories. The theoretical feasibility of the product refers to the conditions, objectives, and processes in the PFCS strategy which accommodates thinking processes in problem solving and information management through students' critical thinking skills.
\end{abstract}

Keywords: problem focused coping skill; critical thinking skill; developmental counselling

\begin{abstract}
Abstrak: Keterampilan berpikir kritis menjadi salah satu keterampilan berpikir yang diperlukan siswa untuk menjadi sumber daya manusia yang berkarakter. Proses penumbuhan keterampilan berpikir saat ini banyak dilakukan secara kontekstual dalam implementasi materi pembelajaran, sedangkan keterampilan berpikir kritis turut dibutuhkan dalam situasi kehidupan sehari-hari. Layanan konseling developmental melalui strategi PFCS menjadi alternatif untuk menumbuhkan keterampilan berpikir kritis melalui situasi kontekstual dalam kehidupan siswa sehari-hari. Metode yang digunakan dalam penelitian ini berdasarkan pada model penelitian dan pengembangan melalui tahap studi pendahuluan, pengembangan produk dan validasi ahli. Subyek penelitian merupakan penilai kelayakan produk, yakni ahli konseling, ahli media pembelajaran, dan calon pengguna. Analisis data hasil penilaian menggunakan statistik deskriptif dan analisa keberterimaan Aiken. Hasil penelitian menunjukkan: (1) adanya kebutuhan pengembangan produk berdasarkan kajian literatur dan data lapangan; (2) strategi PFCS telah berhasil dikembangkan dalam bentuk format dan isi pada fungsi layanan developmental untuk menumbuhkan keterampilan berpikir kritis siswa sekolah menengah atas; (3) hasil penilaian dari para ahli konseling, ahli media pembelajaran, dan pengguna menunjukkan indeks validitas pada kategori layak dan berterima. Kelayakan teoritis produk ini merujuk pada kondisi, tujuan, dan proses pada strategi $P F C S$ yang mewadahi proses-proses berpikir dalam pemecahan masalah dan pengelolaan informasi melalui keterampilan berpikir kritis siswa.
\end{abstract}

Kata kunci: problem focused coping skill; berpikir kritis; konseling developmental 


\section{INTRODUCTION}

The progress of a nation can be started from education as a means and a forum for shaping the character of students. Character is closely related to education, this is because character is the foundation and spirit of education so that the concept of character education emerges (Qomar, 2012). Character education in Indonesia is contained in Strengthening Character Education which is listed in Presidential Regulation Number 87 of 2017. Strengthening character education includes an integration of four aspects which include feeling, heart, mind, and sports with five-character values contained in it as an effort to build national character. The expected national character is a character that provides encouragement in choosing and determining the best in life.

Character values formulated in strengthening character education are a form of government efforts to prepare human resources who are able to compete competitively in the era of the industrial revolution (Wijanarti, Degeng, \& Untari, 2019). The Industrial Revolution 4.0 era faced by Indonesia nowadays demands human resources who continue to innovate and have spiritual awareness who are able to show good attitudes collectively and individually. One of the attitudes in the character developed in adolescents as students is a high curiosity for knowledge.

Adolescents are in a state of high curiosity due to experiencing the process of searching for identity (Hsee \& Ruan, 2016; Sanders, 2013). The process of extracting this knowledge supports the development of adolescents as students and as members of society. However, it can also have a negative impact if this curiosity is not properly controlled and directed (Dubey \& Griffiths, 2017). In this condition, high-order thinking skills are a necessity for adolescents to be able to manage the information obtained so that they can construct appropriate knowledge.

The existence of critical thinking skills allows a person to face and understand objective reality by gaining reliable knowledge about the world (Alexander, 2014). In turn, it enables a person to make a better living, achieve success in life, be better at solving life's problems, and be reconciled with circumstances, mortality, and the universe. The ideal critical thinker is usually curious, knowledgeable, trustworthy, open-minded, flexible, honest in evaluation, honest in dealing with personal biases, wise in making judgments, willing to reconsider and persistent in getting the right results (Murphy et al., 2014).

Critical thinking skills are one of the Higher Order Thinking Skill (HOTS) assessments (Ku \& Ho, 2010). HOTS is a skill based on Bloom's revised taxonomy (Vidergor \& Krupnik-Gottlieb, 2015). Bloom's taxonomy consists of two dimensions, namely the knowledge dimension and the cognitive process dimension. The cognitive process dimension includes six levels, namely remembering $(\mathrm{C} 1)$, understanding (C2), applying (C3), analyzing (C4), evaluating (C5), and creating (C6). The level of thinking to remember $(\mathrm{C} 1)$, understand (C2), and apply (C3) is categorized as low-level thinking skills, while the level of thinking to analyze (C4), evaluate (C5), and create (C6) is categorized as HOTS (Widana, 2017).

Critical thinking involves a complex arrangement of HOTS, in the process, critical thinking involves understanding to evaluate a situation or information. Even in certain conditions, it also involves the level of thinking to create a conclusion which is a new idea or problem solving. Critical thinking, which includes HOTS, shows the existence of an assessment domain that includes dimensions of complex thinking, information processing, effective communication, collaboration and thinking habits (Morris, 2017). Furthermore, students are required to have more complex thinking skills, the ability to link fragments of information into one unit, and the ability to transfer more complex concepts in new situations. Based on this, it can be concluded that one of the HOTS components is the ability to manage information that appears in critical thinking skills.

Critical thinking skills can be broadly conceptualized as a combination of knowledge, skills, and attitudes that facilitate purposeful thinking, problem solving and decision making. A person will be happier if he has reliable knowledge and lives in an objective reality than to live in ignorance and have false or unreliable beliefs. In addition, critical thinking skills have important benefits in helping students live effectively in society, make better judgments, and make personal, business, or leadership decisions (Braun, 2004; Klaczynski, 2001; Pitts, Anderson, \& Haney, 2018).

Students can achieve maximum cognitive effort in society when they do critical thinking in dealing with social life situations. Critical thinking skills are one of the determining factors for the direction of belief and adaptive student behaviour. Critical thinking skills are a component of skills that can generate 
and process information and can guide behaviour if it is based on a strong intellectual commitment (Weissberg, 2013). High school students need to have critical thinking skills in order to become human with character.

A preliminary study conducted on high school students in Malang, Indonesia, showed that students' critical thinking skills are still low. The low critical thinking skills of students have an effect on career fulfillment or student achievement. Critical thinking skills are an important part of the educational process to support students' achievement (Ennis, 2018; Liu et al., 2018). Efforts to develop critical thinking skills are mostly carried out through learning activities in the context of the material being studied. However, not all students are able to translate these critical thinking skills in the context of everyday life (Ennis, 2018; McVey, 2012). In turn, the development of critical thinking skills also needs to be translated in the form of implementing critical thinking in the context of the conditions of students' daily life, especially regarding the conditions of the various life problems it faces. Thus, the school counsellors or counsellors need to have a special strategy in solving the problem of low student critical thinking skills.

Various strategies for guidance and counselling services in developmental functions serve as a bridge for school counsellors or counsellors to be able to assist students in developing students' critical thinking skills. The developmental function of guidance and counselling services is generally carried out in a comprehensive guidance service that focuses on the needs of students in general. In addition, counselling services tend to be chosen in the implementation of the curative function of guidance and counselling. In fact, counselling services have a form of contextual problem-solving exercises on student problem conditions that can be further implemented as a student developmental function.

Implementation of counselling services in student developmental functions through forms of problem solving involves thinking skills that are in line with the critical thinking skills model. The final result of the critical thinking process in the form of the best data conclusion to use as a basis for decision making is the same condition in the form of problem solving in the counselling process. Thus, counselling services can be a form of responsibility that can be given by school counsellors in helping students to improve their critical thinking skills.

The counselling service that can be provided to students in this case is cognitive behavior therapy which functions as a curative-developmental. Cognitive behaviour therapy helps counselees to change behaviour through cognitive changes that will lead to changes in affection and behaviour (Beck, 2011; Hidayah, 2015; Ramli, 2005). Critical thinking skills can be grown with material content that is not related to specific knowledge, but tends to be drawn to students' problems in everyday life (Magno, 2010). Therefore, one strategy that can be used in cognitive counselling to help students develop critical thinking skills is through problem solving exercises (Weissberg, 2013).

The strategy used in this study to foster critical thinking skills of high school students is using the PFCS strategy. PFCS is a coping skill strategy that is often used in curative service functions, namely in alleviating counselee problems. However, this strategy has other advantages that can be used as a developmental strategy, namely in the simulation of problem solving in the process of changing cognition through the process of resource accumulation, identification of potential stress, initial appraisal, and initial coping efforts (Aspinwall \& Taylor, 1997). The use of these advantages in the context of developmental service functions is expected to provide opportunities for students to develop critical thinking processes in managing their knowledge for solving problems in order to achieve the desired achievement or success.

PFCS has been proven effective as an intervention to the cognitive aspects of students with the specification of coping directions which refer to the problems faced, both in the form of confrontation with irrational beliefs and problem solving constructs (Abdollahi \& Carlbring, 2017; de Almeida Santos $\&$ Benevides Soares, 2018; Sharmila, 2016). The PFCS strategy involves modifying existing problems and information and usually includes elements such as generating options for solving problems, evaluating the impact of various options, and implementing steps to solve the problem (Lazarus \& Folkman, 1984). Therefore, a PFCS guideline was developed as a strategy to develop students' critical thinking skills. 


\section{METHOD}

This study employed a development model (Akker et al., 2006) with special adjustments that refer to the research objectives. The procedure includes: (1) a preliminary study which is a data collection of needs through a literature study process and interviews with school counsellors and/or counsellors as guidance and counselling practitioners, (2) product development through model construction based on theoretical and contextual studies of the PFCS strategy and critical thinking skills which as manifested in a guidebook, (3) product evaluation in the form of assessment and validation by experts related to the product being developed.

Participants involved in this study were two counselling experts, two learning media experts and eight counsellors. Counselling experts with qualifications as guidance and counselling lecturers with at least five years of experiences were responsible for providing an assessment of product material related to the counselling strategy used and the thinking skills process that is targeted. Instructional media experts with qualifications as educational technology lecturers with at least five years of experience were responsible for assessing the feasibility of products developed as learning media for school counsellors. School counsellors and/or counsellors as guidance and counselling practitioners with minimum experience qualifications of five years are potential users of products that have been developed, so they have a role to provide product assessment in terms of practical product use. All participants were involved in the evaluation, assessment and validation process of the PFCS guideline product to foster critical thinking skills of high school students.

The assessment was carried out using an instrument in the form of a validation assessment questionnaire that assesses the feasibility of the aspects of clarity, accuracy, and convenience of the developed product. The clarity aspect refers to how the product shows clarity in the form of the format as a medium and the content of the counselling strategy material developed. The aspect of accuracy is described in the forms of selecting images, designs, colours, etc. as a medium, as well as the accuracy of the structure and systematics of content, material concepts and the suitability of the material to development objectives. The aspect of convenience relates to format choices for readers to use and study the developed product, as well as the ease with which readers understand the structure of the concept to be understood and implemented. These three aspects are further elaborated in the respective assessment instruments for counselling experts, media experts and prospective users.

Data garnered from the assessment of the appraisers were analyzed by calculating the Aiken validity index (1980). The use of this analysis is based on the Aiken validity index calculation model that compares the score against the range of scores and the number of respondents. The calculation of the Aiken validity index, which has a constant formula for any number of respondents, is necessary in this study, which has a different number of respondents in the assessment. The overall results of the analysis become a series of data to obtain feasibility in the form of theoretical acceptance of the PFCS strategy to foster high school students' critical thinking skills.

\section{RESULTS}

The preliminary study informs the need to develop a PFCS strategy to foster high school students' critical thinking skills. Exposure to these needs conditions is based on the development needs of the characteristics of students who have HOTS. High school students need critical thinking skills to become superior human resources during the 4.0 Industrial Revolution.

Similar conditions were also found in the results of interviews with several high school counsellors in Malang, Indonesia. The counsellors described some of the obstacles students had as a form of their lack of critical thinking skills. Some of the conditions for these obstacles include: (1) being easily influenced by invitations to ditch friends, (2) easily influenced by friends' invitation to smoke, (3) disputes often occur due to misinformation, and (4) passive in learning. The results of further in-depth analysis found that the students lacked skills in understanding the situation at hand, thus leading them to wrong or incorrect conclusions. Thus, critical thinking skills emerge as a necessity for high school students.

The product that has been developed is the PFCS strategy to foster high school students' critical thinking skills. Product development begins with a literature review of students' critical thinking skills and the PFCS strategy. The literature review provides the theoretical basis for product development. 
The next study relates to the formulation of a developmental PFCS strategy to foster students' critical thinking skills. The formulation integrates the procedures in the PFCS strategy and the stages in critical thinking. One example of this formulation is changing the problem as the main focus of the coping implementation process, which involves the process of illustrating the problem so that it does not constantly focus on student problems. The existence of this illustration becomes a media for students to practice applying critical thinking skills in various life conditions.

The PFCS strategy was developed in the form of a counselling guide to cultivate high school students' critical thinking skills. The embodiment of this guide product uses materials that have been considered in terms of beauty, durability, and price. The guidebook size that has been considered is the B5 size $(182 \mathrm{~mm} \times 257 \mathrm{~mm})$. The material selection for the guide cover is to use Glory 260 -gram art-paper. Meanwhile, the content page used HVS paper which is in accordance with the needs of the contents of the guide which does not contain too many colour images.

The content of the counselling manual using the PFCS strategy to cultivate high school students' critical thinking skills consists of four parts, namely the introduction section, conceptual study, strategy implementation procedures, and strategy implementation assessment. Introduction (part 1) is prepared to explain the rationale for the need for PFCS counselling to foster critical thinking skills of high school students. It proceeds with the PFCS strategic objectives, followed by a description of the target users and the strategic objectives. The final explanation of this section is how to use a guide that describes ways that school counsellors can carry out counselling with the PFCS strategy to foster critical thinking skills of high school students.

The assessment of the two counselling experts showed the theoretical feasibility of the material and content of the PFCS strategy guide product to foster critical thinking skills of high school students in the proper and acceptable categories. This condition is shown from the assessment of the clarity aspect at the validity index score of 0.81 , including in the high category. Furthermore, the aspect of assessing the accuracy shows that the validity index results at 0.80 are in the high category. Overall, the final result of the assessment is in the high category with the final result of the validity index at 0.80 . Thus, the product of the PFCS strategy guide has met the criteria for the feasibility and theoretical acceptability of the material and content as a counselling strategy for use by school counsellors in schools.

The assessment of the two instructional media experts showed the theoretical feasibility of the material and content of the PFCS strategy guide product to foster critical thinking skills of high school students in the proper and acceptable categories. This condition is shown from the assessment on the aspect of the guide measure showing the validity index at 1.00 which is in the high category. Furthermore, the assessment aspect of the guidebook cover design shows the results on the validity index score of 0.83 are also in the high category. The assessment aspect of the guidebook content design shows that the validity number 1.00 is in the high category. Overall, the final result of the assessment is in the high category with a validity index of 0.94 . Thus, the product of the PFCS strategy guide has met the criteria for feasibility and theoretical acceptability of form and format as a learning medium for use by school counsellors in schools.

The results of the assessment of eight counsellors as potential users showed the practical feasibility of the material and product content of the PFCS strategy guide to foster critical thinking skills of high school students in the proper and acceptable categories. This condition is shown from the assessment of the clarity aspect on the validity index of 0.76 which is included in the high category. Furthermore, the aspect of assessing the accuracy shows the validity index result of 0.78 which is in the high category. Overall, the final result of the assessment is in the high category with an assessment of the validity index score of 0.77 . Thus, the product of the PFCS strategy guide has met the criteria for practical feasibility and acceptance as a counselling strategy guide for use by school counsellors in schools.

This has shown several descriptions of the feasibility and theoretical validity of the PFCS strategy product to foster critical thinking skills of high school students. This exposure is indicated by research results in the form of product development needs based on the results of a literature review and interviews with school counsellors. Furthermore, the product has been successfully developed by having a form and format that is ready to be used as a learning medium for counsellors, as well as content and material that shows the results of developing PFCS in the context of developmental services to foster critical thinking skills of high school students. The results of the evaluation and expert assessment in particular 
have shown the feasibility of the product being developed in the elements of feasibility as a learning medium, feasibility as a material and counselling strategy concept, and feasibility as a strategy to be used by school counsellors.

\section{DISCUSSION}

Product acceptance has been shown based on the assessment results from experts and potential users or practitioners. The product developed has shown acceptance as a counselling service strategy based on the assessment of counselling materials by the counselling experts. The product also shows acceptance as a suitable learning medium for use by school counsellors. Both expert assessments are reinforced by practitioners' assessments of the practicality of the product to be used by school counsellors/counsellors to help students develop critical thinking skills.

The PFCS strategy used as a developmental counselling strategy demonstrates its theoretical feasibility. This condition refers to coping strategies and techniques that have the aim of increasing self-control capacity through awareness of inner-cognitive processes that affect behaviour and emotions (Meichenbaum, 1977). In the process, capacity building in the inner-cognitive process becomes a form of training in developmental functions. The cognitive processes that have been successfully carried out can then be generalized and applied to various aspects of the counselee's daily life.

Furthermore, PFCS focuses on how a person provides evaluation as a form of an inner-cognitive process towards problem situations to determine the next emotional reaction. Thus, an individual can obtain a more effective coping repertoire by learning to modify his cognitive "set" in dealing with situations that cause problems. Effective repertoire coping can show as a flexible strategy when implemented in a variety of situations (Loh et al., 2018).

The cognitive alteration process in the PFCS strategy will shape the counselee's thinking process at a higher level. This condition refers to the study of everyday problem situations through the process of identification, evaluation and problem solving. The results of this thought process will form the counselee's automatic thought in the cognitive set at a high level (Sharmila, 2016). The counselee's skills in managing automatic thought as a manifestation of effective repertoire coping that can be implemented in various situations of everyday life.

The existence of a cognitive process that involves higher-order thinking in the stages of the PFCS strategy can be the basis for theoretical feasibility to be used as an effort to foster students' critical thinking skills. PFCS strategic intervention involves critical thinking processes in the form of reasoning, analysis, problem solving, reading comprehension, scientific thinking, creative thinking, assessment, and accurate decision making (Sarigoz, 2012; Song, 2016) while reconstructing counselees' thinking. The results of this thinking process will be used by individuals as knowledge which will be internalized as belief (Alexander, 2014; Hassan \& Madhum, 2007).

The thought process in forming this knowledge is a form of individual high-level thinking process in the form of metacognition. Individuals analyze the information that has been stored into their cognition for in-depth analysis, so that understanding, meaning and knowledge structure can be obtained from the process (Magno, 2010; Xu \& Huang, 2018). The process of the presence of constructive knowledge serves as individual belief. At this point, a person's belief construction can determine how their feelings and behaviour are adaptive, or otherwise it is mal-adaptive (Beck, 2011). Belief construction can be done by restructuring cognitive core belief (Jansson-Fröjmark et al., 2016; Malkinson, 2010), as well as fighting automatic thoughts through coping (Hoffmann, 2016). Changing belief through coping, which is done in this study, occurs by involving evaluations to find adaptive automatic thoughts from the counselees.

Furthermore, critical thinking skills use a person's information and knowledge to find the best alternative to solve problems. This condition makes critical thinking deal with problem situations, and changes the ideas within and around them to be used in the analysis and evaluation process to achieve success (Weissberg, 2013). Changing ideas based on analysis and evaluation in critical thinking certainly contributes to changing knowledge and into belief construction in the PFCS strategy. The exposure of this study shows the similarity of conditions and objectives in the PFCS strategy and critical thinking. 
The theoretical feasibility of the PFCS strategy to develop critical thinking skills also refers to the process of constructing automatic thought into adaptive belief. This condition is present when the individual begins to collect information about the problem situation or resource accumulation; identify potential problems or identification of potential stress; reasoning and problem analysis or initial appraisal; constructing problem solving or initial coping efforts, and evaluating the construction results of solving problems or elicitation and use of feedback (Aldwin, 2007). The five stages of the PFCS strategy demand an important role for individual cognition in higher order thinking.

The role of cognition in the PFCS strategy process is in line with the critical thinking process in individuals. The critical thinking process is manifested when individuals carry out analytical studies in the processes of argumentation, assumption, deduction, interpretation to conclusion. (Gadzella et al., 2006, 2005; Mirzaee \& Maftoon, 2016; Zulmaulida, Wahyudin, \& Dahlan, 2018). Metacognition processes helps knowledge to arrive at conclusions that become understandings which are ultimately internalized by individuals in themselves (Pitts et al., 2018). The conditions of the PFCS strategy and critical thinking skills show the similarity of elements in the process of knowledge and belief construction through identification, reasoning and analysis, problem solving construction, and conclusion based on evaluation of a situation.

\section{CONCLUSION}

The present study unravels the theoretical feasibility of the PFCS strategy to foster high school students' critical thinking skills. The developed product is feasible in terms of counselling materials, learning media, and practical aspects for use by school counsellors and/or counsellors. The PFCS strategy encompasses conditions, objectives, and processes that can be used to foster students' critical thinking skills. The processes of identification, reasoning, analysis, and evaluation are used in forming new knowledge through higher thinking processes. Strengthening these findings can be carried out through tests and the implementation of this strategy for students to obtain practical-implementable acceptance.

\section{REFERENCES}

Abdollahi, A., \& Carlbring, P. (2017). Coping style as a moderator of perfectionism and suicidal ideation among undergraduate students. Journal of Rational - Emotive and Cognitive - Behavior Therapy, 35(3), $223-239$.

Akker, J., Gravemeijer, K., Mckenney, S. M., \& Nieven, N. (2006). Educational design research. New York: Routledge.

Aldwin, C. M. (2007). Stress, coping, and development: an Integrative perspective. New York: Guilford.

Alexander, P. A. (2014). Thinking critically and analytically about critical-analytic thinking: an Introduction. Educational Psychology Review, 26(4), 469-476.

Aspinwall, L. G., \& Taylor, S. E. (1997). A stitch in time: Self-regulation and proactive coping. Psychological Bulletin, 121(3), 417-436.

Beck, J. (2011). Cognitive behavior therapy: Basics and beyond.

Braun, N. M. (2004). Critical thinking in the business curriculum. Journal of Education for Business, 79(4), $232-236$.

de Almeida Santos, Z., \& Benevides Soares, A. (2018). Social skills, coping, resilience and problem-solving in psychology university students. Liberabit: Revista Peruana de Psicología, 24(2), 265-276.

Dubey, R., \& Griffiths, T. L. (2017). A rational analysis of curiosity. 39th Annual Conference of the Cognitive Science Society (CogSci).

Ennis, R. H. (2018). Critical thinking across the curriculum: A vision. Topoi, 37(1), 165-184.

Gadzella, B. M., Hogan, L., Masten, W., Stacks, J., Stephens, R., \& Zascavage, V. (2006). Reliability and validity of the Watson-Glasere critical thinking appraisal-forms for different academic groups. Journal of Instructional Psychology, 33(2), 141-143.

Gadzella, B. M., Stacks, J., Stephens, R. C., \& Masten, W. G. (2005). Watson-Glaser critical thinking appraisal, Form-S for education majors. Journal of Instructional Psychology, 32(1), 9-12. 
Hassan, K. El, \& Madhum, G. (2007). Validating the Watson Glaser critical thinking appraisal. Higher Education, 54(3), 361-383.

Hidayah, N. (2015). Cognitive-behavioral cyber counselling to improve junior high school student's self-regulated learning. International Journal Academic Research, 7(4), 241-243.

Hoffmann, M. H. G. (2016). Reflective argumentation: A cognitive function of arguing. Argumentation, 30(4), 365-397.

Hsee, C. K., \& Ruan, B. (2016). The pandora effect: The power and peril of curiosity. Psychological Science, 27(5), 659-666.

Jansson-Fröjmark, M., Danielsson, K., Markström, A., \& Broman, J. E. (2016). Developing a cognitive behavioral therapy manual for delayed sleep-wake phase disorder. Cognitive Behaviour Therapy, 45(6), 518-532.

Klaczynski, P. A. (2001). Framing effects on adolescent task representations, analytic and heuristic processing, and decision making: Implications for the normative/descriptive gap. Journal of Applied Developmental Psychology, 22(3), 289-309.

$\mathrm{Ku}, \mathrm{K}$. Y. L., \& Ho, I. T. (2010). Metacognitive strategies that enhance critical thinking. Metacognition and Learning, 5(3), 251-267.

Lazarus, R. S., \& Folkman, S. (1984). Stress, appraisal, and coping. New York: Springer Publishing Company.

Liu, O. L., Shaw, A., Gu, L., Li, G., Hu, S., Yu, N., ... Loyalka, P. (2018). Assessing college critical thinking: preliminary results from the Chinese HEIghten ${ }^{\circledR}$ Critical Thinking assessment. Higher Education Research and Development, 37(5), 999-1014.

Loh, K. Y., Elsayed, I., Nurjahan, M. I., \& Roland, G. S. (2018). Item difficulty and discrimination index in single best answer MCQ: End of semester examinations at Taylor's Clinical School. In Redesigning Learning for Greater Social Impact (pp. 167-171).

Magno, C. (2010). The role of metacognitive skills in developing critical thinking. Metacognition and Learning, $5(2), 137-156$.

Malkinson, R. (2010). Cognitive-behavioral grief therapy: The ABC model of rational-emotion behavior therapy. Psihologijske Teme, 19(2), 289-305.

McVey, M. (2012). Classrooms of wonder and wisdom: Reading, writing, and critical thinking for the 21st century. International Review of Education, 58(1), 145-146.

Meichenbaum, D. (1977). Cognitive-behavior modification: An integrative approach.

Mirzaee, S., \& Maftoon, P. (2016). An examination of Vygotsky's socio-cultural theory in second language acquisition: the role of higher order thinking enhancing techniques and the EFL learners' use of private speech in the construction of reasoning. Asian-Pacific Journal of Second and Foreign Language Education, 1(1). 18

Morris, L. V. (2017). Moving beyond critical thinking to critical dialogue. Innovative Higher Education, 42(5-6), $377-378$.

Murphy, P. K., Rowe, M. L., Ramani, G., \& Silverman, R. (2014). Promoting critical-analytic thinking in children and adolescents at home and in school. Educational Psychology Review, 26(4), 561-578.

Pitts, C., Anderson, R., \& Haney, M. (2018). Measures of instruction for creative engagement: Making metacognition, modeling and creative thinking visible. Learning Environments Research, 21(1), 43-59.

Qomar, M. (2012). Kesadaran pendidikan sebuah penentu keberhasilan pendidikan. Jakarta: Arrus Media.

Ramli, M. (2005). Terapi perilaku kognitif. In Pendidikan dan konseling di era global. Bandung: BK UPI.

Sanders, R. A. (2013). Adolescent psychosocial, social, and cognitive development. Pediatrics in Review, 34(8), $354-359$.

Sarigoz, O. (2012). Assessment of the high school students' critical thinking skills. Procedia - Social and Behavioral Sciences, 46, 5315-5319.

Sharmila, S. (2016). Emotion and problem focused coping strategies: A comparative study of male and female engineering students in Chennai City. International Journal of Advance Research in Computer Science and Management Studies, 4(8), 222-224.

Song, X. (2016). 'Critical thinking' and pedagogical implications for higher education. East Asia, 33(1), 25-40.

Vidergor, H. E., \& Krupnik-Gottlieb, M. (2015). High order thinking, problem based and project based learning in blended learning environments. In Applied Practice for Educators of Gifted and Able Learners (pp. 217-232).

Weissberg, R. (2013). Critically thinking about critical thinking. Academic Questions, 26(3), 317-328. 
Widana, I. W. (2017). High order thinking skills assessment (HOTS). Journal of Indonesian Student Assessment and Evaluation, 3(1), 32-44.

Wijanarti, W., Degeng, I. N. S., \& Untari, S. (2019). Problematika pengintegrasian penguatan pendidikan karakter pada pembelajaran tematik. Jurnal Pendidikan: Teori, Penelitian, dan Pengembangan, 4(13), 393-398.

Xu, J., \& Huang, Y. T. (2018). The mediating effect of listening metacognitive awareness between listening test anxiety and listening test performance. Asia-Pacific Education Researcher, 27(4), 313-324.

Zulmaulida, R., Wahyudin, \& Dahlan, J. A. (2018). Watson-Glaser's critical thinking skills. Journal of Physics: Conference Series, 1028(1), 1-6. 